\title{
Benthic Diatoms on Sheltered Coastal Soft Bottoms (Baltic Sea)-Seasonal Community Production and Respiration
}

\author{
Ulf Karsten $^{1, * \mathbb{D} \text {, Kana Kuriyama }}{ }^{1}$, Thomas Hübener ${ }^{2}$ and Jana Woelfel ${ }^{3}$ \\ 1 Applied Ecology and Phycology, Institute of Biological Sciences, University of Rostock, \\ D-18057 Rostock, Germany; kana.kuriyama@uni-rostock.de \\ 2 Botany, Institute of Biological Sciences, University of Rostock, D-18057 Rostock, Germany; \\ thomas.huebener@uni-rostock.de \\ 3 Aquatic Ecology, Institute of Biological Sciences, University of Rostock, D-18057 Rostock, Germany; \\ jana.woelfel@uni-rostock.de \\ * Correspondence: ulf.karsten@uni-rostock.de; Tel.: +49-381-4986090; Fax: +49-381-4986072
}

Citation: Karsten, U.; Kuriyama, K.; Hübener, T.; Woelfel, J. Benthic Diatoms on Sheltered Coastal Soft Bottoms (Baltic Sea)-Seasonal Community Production and Respiration. J. Mar. Sci. Eng. 2021, 9, 949. https://doi.org/10.3390/ jmse9090949

Academic Editor: Juan Miguel Soria

Received: 16 August 2021

Accepted: 27 August 2021

Published: 31 August 2021

Publisher's Note: MDPI stays neutral with regard to jurisdictional claims in published maps and institutional affiliations.

Copyright: (c) 2021 by the authors. Licensee MDPI, Basel, Switzerland. This article is an open access article distributed under the terms and conditions of the Creative Commons Attribution (CC BY) license (https:/ / creativecommons.org/licenses/by/ $4.0 /)$.

\begin{abstract}
Benthic diatom communities dominate sheltered shallow inner coastal waters of the atidal Southern Baltic Sea. However, their photosynthetic oxygen production and respiratory oxygen consumption is rarely evaluated. In the Baltic Sea carbon budget benthic diatom communities are often not included, since phytoplankton is regarded as the main primary producer. Therefore, two wind-protected stations (2-49-cm depths) were investigated between July 2010 and April 2012 using undisturbed sediment cores in combination with planar oxygen optodes. We expected strong fluctuations in the biological activity parameters in the incubated cores over the course of the seasons. The sediment particles at both stations were dominated by fine sand with a median grain size of 131-138 $\mu \mathrm{m}$ exhibiting an angular shape with many edges, which were less mobile compared to exposed coastal sites of the Southern Baltic Sea. These sand grains inhabited dense communities of rather small epipsammic diatoms $(<10 \mu \mathrm{m})$. Chlorophyll $a$ as a biomass parameter for benthic diatoms fluctuated from 64.8 to $277.3-\mathrm{mg}$ Chl. $a \mathrm{~m}^{-2}$ sediment surface. The net primary production and respiration rates exhibited strong variations across the different months at both stations, ranging from 12.9 to $56.9 \mathrm{mg} \mathrm{O}_{2} \mathrm{~m}^{-2} \mathrm{~h}^{-1}$ and from -6.4 to $-137.6 \mathrm{mg} \mathrm{O}_{2} \mathrm{~m}^{-2} \mathrm{~h}^{-1}$, respectively. From these data, a gross primary production of 13.4 to $59.5 \mathrm{mg} \mathrm{C} \mathrm{m}^{-2} \mathrm{~h}^{-1}$ was calculated. The results presented confirmed strong seasonal changes (four-fold amplitude) for the activity parameters and, hence, provided important production biological information for sheltered sediments of the Southern Baltic Sea. These data clearly indicate that benthic diatoms, although often ignored until now, represent a key component in the primary production of these coastal habitats when compared to similar studies at other locations of the Baltic Sea and, hence, should be considered in any carbon budget model of this brackish water ecosystem.
\end{abstract}

Keywords: microphytobenthos; primary production; Baltic Sea; chlorophyll; biomass

\section{Introduction}

The Baltic Sea is a geologically young shelf sea in Northern Europe characterized by a strong horizontal salinity gradient leading to brackish conditions, as well as by a lack of tides [1].Only in the western part of the Baltic Sea, a small tidal range of 12-15 cm can be detected, which gets even lower towards its eastern part-for example,$<5 \mathrm{~cm}$ at the Bay of Gdansk, Poland [2]. Nevertheless, the wind speed and direction, along with atmospheric pressure, can temporarily lead to changed sea water levels because of high waves [3]. The Southern Baltic Sea coast is geomorphologically characterized by a highly dynamic mosaic pattern of eroding cliffs and sand deposition areas [1]. Consequently, most of the coastal area between 0 and $10 \mathrm{~m}$ depth is covered by coarse-grained sediments. In the shallowest water, fine and medium sands dominate because of the presence of frequent waves and strong winds generating longshore currents, which displace the small particles 
and transport them along the coast [1]. Both processes of abrasion and sedimentation steadily result in the loss of terrestrial materials and, in parallel to the formation of shallow subtidal flats, spits and lagoon systems [4,5].

Such protected areas are commonly occupied by benthic diatoms as dominant phototrophic microorganisms forming diverse microphytobenthic communities [6]. Benthic diatoms in shallow coastal regions are considered as important primary producers responsible for up to $30 \%$ of carbon fixation of this ecosystem [6,7], and thus, they are suppliers of organic compounds to grazers and to deposit feeders such as macro- and meiofauna [8,9], as well as to bacteria [10]. Part of this organic carbon is excreted as sticky extrapolymeric substances (EPS), which stabilize and modify sediment surfaces [11]. As a consequence, hydrodynamic erosion is reduced, and the vertical exchange of dissolved gases such as oxygen and of nutrients is controlled at the soft bottom-water column interface [12].

Microphytobenthic communities typically consist of various phototrophic algal groups, such as Bacillariophyceae, Chlorophyceae, Dinophyceae, and Cyanobacteria, but benthic diatoms often dominate in terms of biodiversity and biomass [13-15]. These taxa live either in the interspaces and porewater between soft bottom particles (=epipelic) or directly attached to soft bottom particles (=epipsammic) in the top millimeters of such coastal sedimentary structures [16]. The sediment type and the degree of exposition (disturbance) control the diatom activity, since small-sized epipsammic taxa typically occur on exposed sandy sediments ([15] and the references therein), whereas larger epipelic species are limited by sand-scouring processes [17]. The distribution of the soft bottom grain-size along with their hydrodynamically influenced dynamics can affect the benthic diatom biomass and productivity [18]. Therefore, the wind conditions are a key factor for the strength of currents and waves that physically shape and even disturb exposed sediments and their inhabitants in the Southern Baltic Sea [15], while, at sheltered, soft bottom sites, these forces are dampened.

Although microphytobenthic communities play a key functional role as primary producers on tidal flats such as the Wadden Sea and in estuaries $[19,20]$, this ecological function has been much less studied in the Southern Baltic Sea, for example, at exposed coastal sites [15], in some inner coastal waters [21-23], or the Bay of Gdansk (Poland) [24]. While Kuriyama et al. [15] reported 16.3-74.0 $\mathrm{mg} \mathrm{C} \mathrm{m}^{-2} \mathrm{~h}^{-1}$ (gross primary production rate) at shallow sampling depths between 3.0 and $6.2 \mathrm{~m}$ (April-July 2017), the other investigations indicate lower values of 0.2 up to $41.8 \mathrm{mg} \mathrm{C} \mathrm{m}^{-2} \mathrm{~h}^{-1}$ that were influenced by soft bottom particle sizes, depths, and dates (season) of the respective study site. These differences can be explained by prevailing the environmental parameters of the different study sites (sheltered lagoon versus exposed sandy beach) and by applying different measuring techniques, such as ${ }^{14} \mathrm{C}$ incubation and oxygen electrodes, which hamper the direct comparison of the published data [15].

The main goal of the present investigation was to evaluate microphytobenthic primary production between July 2010 and April 2012 at a shallow-water site $(<5-40 \mathrm{~cm}$ water depth), which is protected by a peninsula, the so-called 'Boiensdorfer Werder' opposite of the island Poel, Southern Baltic Sea [25], where wind- and wave-induced mixing of the upper soft bottom layer is strongly reduced. Undisturbed sediment cores were taken and treated under controlled and light saturating conditions in the laboratory. This setup measured oxygen changes as consumption rates in the dark (respiration) and production rates in the light (net primary production), by using planar oxygen sensor spots as the recording system [15]. We hypothesized a high photosynthetic activity of the benthic diatom communities over all measuring dates because of the protected environmental conditions at the study site leading to strongly reduced physical disturbance compared to exposed coastal locations. 


\section{Materials and Methods}

\subsection{Site Characteristics and Sampling}

The Boiensdorf site is located at a shallow water area in the "Bight of Wismar" in the vicinity of the island Poel $\left(54^{\circ} 01.490^{\prime} \mathrm{N}, 11^{\circ} 32.110^{\prime} \mathrm{E}\right)$ (Figure 1). Two sampling stations 1 and 2 are representatives for sheltered inner coastal areas of the Southern Baltic Sea due to reduced hydrodynamic forces and rather undisturbed sediment characteristics.

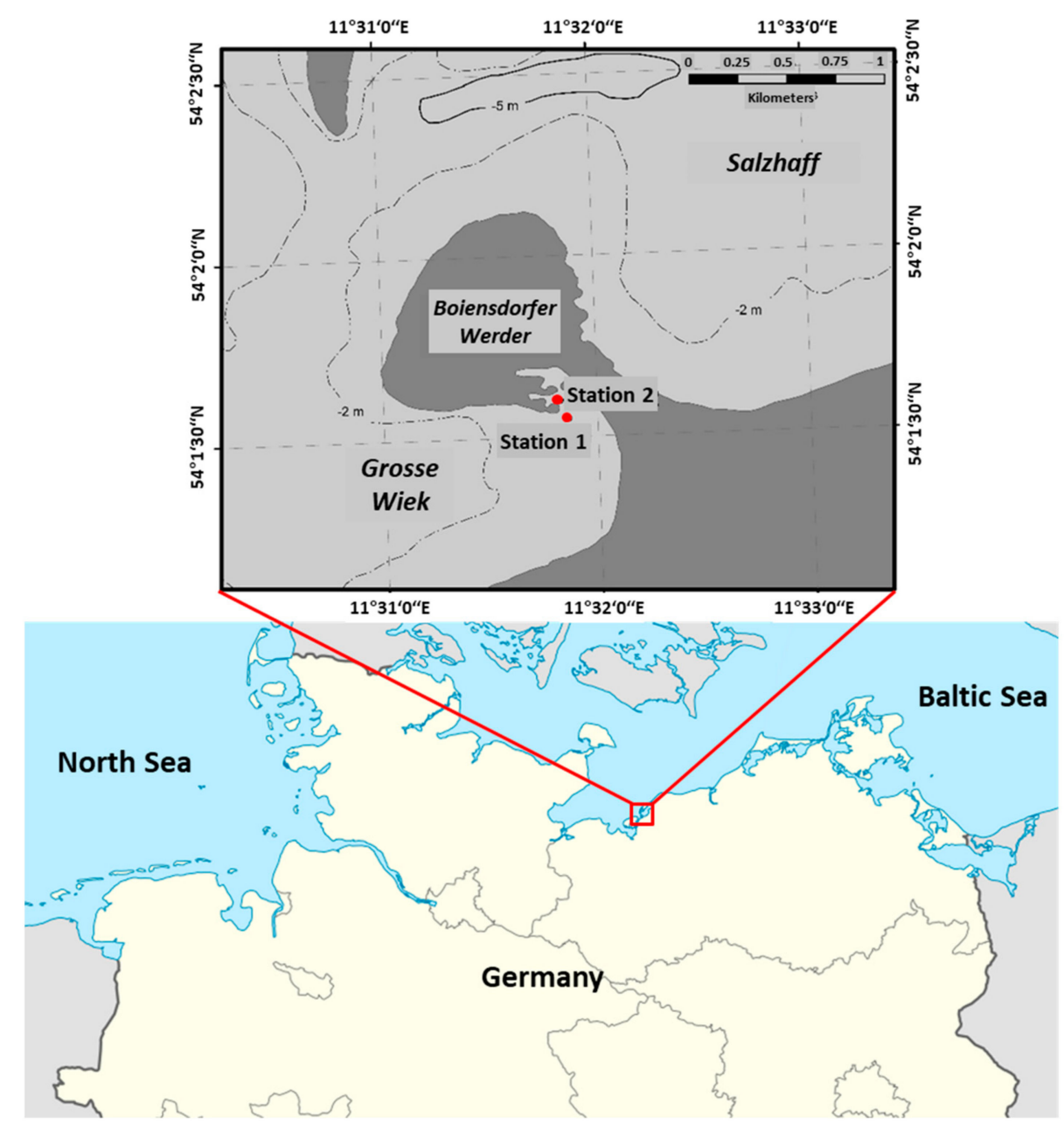

Figure 1. Study site of both sheltered stations S1 and S2 at the Boiensdorfer Werder (southern coast of the German Baltic Sea) where the samples were taken.

The water depth was not exceeding $49 \mathrm{~cm}$ at all sampling dates, as confirmed by our regular field work at the former and now closed marine biological station Boiensdorf, University of Rostock. Sampling was always done using waders and took place between July 2010 and April 2012 (Table 1). During each sampling, the temperature and salinity were monitored in the water column (Multiline P4, WTW, Weilheim, Germany). Plexiglas ${ }^{\circledR}$ core liners (inner $\varnothing 5 \mathrm{~cm}$, height $25 \mathrm{~cm}$ ) were applied at both sites for carefully taking soft bottom samples, which guaranteed an intact layering and minimum disturbance of the cores. These Plexiglas ${ }^{\circledR}$ core liners were pushed about $20 \mathrm{~cm}$ into the soft bottom and straight afterwards closed on top with a rubber plug. Then, the sampling tubes were pulled out of the sediment and closed with another rubber plug at the bottom. Since benthic diatoms typically exhibit heterogeneous distribution on soft bottoms, 3 replicates where taken. The soft bottom samples were transported within 1 to $2 \mathrm{~h}$ after sampling to the laboratory under cool and dark conditions and kept in a cooling room $\left(5^{\circ} \mathrm{C}\right)$ until further processing. Determination of the sediment characteristics, biomass, and primary production/respiration was always done within the next $48 \mathrm{~h}$. 
Table 1. Environmental data on both sampling stations in Boiensdorf $\left(54^{\circ} 01.490^{\prime} \mathrm{N}, 11^{\circ} 32.110^{\prime} \mathrm{E}\right)$. Soft bottom samples were taken between July 2010 and April 2012. Temperature, salinity, and mean grain size are given. For water content, organic matter and molar $\mathrm{CN}$ ratio sediment cores were sampled in the field at different time points. Mean values \pm standard deviation are given $(n=12-15)$. Different lowercase and uppercase letters reflect the results of the one-way ANOVA (significant differences among all means using Tukey's test, $p<0.05$ ).

\begin{tabular}{|c|c|c|c|c|c|c|c|c|c|}
\hline Station & Depth & Month, Year & Temperature & Salinity & Median & & Water & Organic & $\mathrm{C}: \mathrm{N}$ ratio \\
\hline \multirow[t]{2}{*}{ No. } & (m) & & $\left({ }^{\circ} \mathrm{C}\right)$ & $\left(S_{A}\right)$ & Grain Size & & Content & Content & Content \\
\hline & & & & & $(\mu \mathrm{m})$ & & $(\% \mathrm{FW})$ & \multicolumn{2}{|c|}{$\left(\mathrm{mg} \mathrm{g}^{-1} \mathrm{DW}\right)$} \\
\hline \multirow{8}{*}{1} & & & & & & & Mean \pm SD & Mean \pm SD & Mean \pm SD \\
\hline & $0.11-0.49$ & Jul 2010 & 25 & 10 & 131 & & $31.0 \pm 3.0^{\mathrm{a}}$ & $11.3 \pm 2.3^{a}$ & $7.9 \pm 0.2^{\mathrm{a}}$ \\
\hline & & Oct 2010 & 9.1 & 13.4 & & & $36.5 \pm 1.0^{b}$ & $25.0 \pm 1.8^{b}$ & $8.3 \pm 0.6^{\mathrm{a}}$ \\
\hline & & Apr 2011 & 12.9 & 12.6 & & & $27.6 \pm 4.2^{\mathrm{a}}$ & $17.4 \pm 1.7^{\mathrm{c}}$ & $8.6 \pm 0.3^{\mathrm{a}}$ \\
\hline & & Jul 2011 & 23.3 & 11.8 & & & $33.2 \pm 2.2^{\mathrm{a}}$ & $15.8 \pm 0.8^{c}$ & $7.8 \pm 0.2^{\mathrm{a}}$ \\
\hline & & Oct 2011 & 13 & 11.4 & & & $25.8 \pm 0.8^{c}$ & $7.9 \pm 0.4^{\mathrm{d}}$ & $7.4 \pm 0.4^{b}$ \\
\hline & & Apr 2012 & 7.8 & 12.4 & & & $31.1 \pm 1.2^{\mathrm{a}}$ & $12.9 \pm 1.6^{\mathrm{a}}$ & $8.0 \pm 0.3^{\mathrm{a}}$ \\
\hline & & & & & & Mean & $30.9 \pm 3.8^{\mathrm{A}}$ & $15.1 \pm 5.9^{\mathrm{A}}$ & $8.0 \pm 0.4^{\mathrm{A}}$ \\
\hline \multirow[t]{7}{*}{2} & $0.02-0.12$ & Jul 2010 & 26.1 & 10.7 & 138 & & $44.0 \pm 3.9^{c}$ & $19.9 \pm 3.1^{c}$ & $8.1 \pm 0.2^{a}$ \\
\hline & & Oct 2010 & 12.2 & 13.4 & & & $37.3 \pm 3.6^{b}$ & $21.1 \pm 2.4^{c}$ & $7.7 \pm 0.1^{\mathrm{a}}$ \\
\hline & & Apr 2011 & 16.9 & 12.5 & & & $37.3 \pm 2.4^{b}$ & $19.4 \pm 2.1^{c}$ & $7.5 \pm 0.4^{\mathrm{a}}$ \\
\hline & & Jul 2011 & 25.3 & 12.2 & & & $43.6 \pm 0.9^{c}$ & $23.3 \pm 0.9^{d}$ & $7.5 \pm 0.2^{\mathrm{a}}$ \\
\hline & & Oct 2011 & 13.1 & 11.2 & & & $42.0 \pm 2.6^{c}$ & $20.1 \pm 1.8^{c}$ & $7.5 \pm 0.4^{a}$ \\
\hline & & Apr 2012 & 9.9 & 12.1 & & & $45.1 \pm 4.2^{\mathrm{c}}$ & $26.5 \pm 1.1^{\mathrm{d}}$ & $7.2 \pm 0.3^{b}$ \\
\hline & & & & & & Mean & $41.6 \pm 3.4^{\text {в }}$ & $21.7 \pm 2.8^{\mathrm{A}}$ & $7.6 \pm 0.3^{\mathrm{A}}$ \\
\hline
\end{tabular}

\subsection{Biomass and Sediment Properties}

Chlorophyll $a$ (chl. a) content was used as a broadly applied areal proxy for soft bottom microphytobenthic biomass and finally expressed as $\mathrm{mg}$ chl. $a \mathrm{~m}^{-2}$ sediment surface. From each soft bottom core, the top $1 \mathrm{~cm}$ layer was removed with a scraper and carefully mixed in a Petri dish before dividing into 2 subsamples. The first subsample was used for chlorophyll $a$ extraction and quantification, the second one processed for the analysis of soft bottom parameters (water content, organic content, and molar $\mathrm{C}$ to $\mathrm{N}$ ratio). Always, a $1.13-\mathrm{cm}^{3}$ soft bottom sample were extracted in $5-\mathrm{mL} 90 \%$ acetone $(v / v)$ for chl. $a$ quantification ( $24 \mathrm{~h}$ incubation with occasional vortex mixing, dark conditions, and 4 to $5{ }^{\circ} \mathrm{C}$ in a fridge). After $24 \mathrm{~h}$, the extracts were centrifuged in a cooling centrifuge $\left(5^{\circ} \mathrm{C}\right)$ for 5-10 min at $7200 \times g$, and the supernatants were removed from the centrifuge tubes, and their absorbance was measured. Pellets were twice resuspended and re-extracted by the same protocol to improve the extraction efficiency by using $2.5-\mathrm{mL} 90 \%$ acetone each time. All chlorophyll $a$ values were photometrically (UV-2401PC, Shimadzu, Duisburg, Germany) quantified according to Reference [26]. Concentrations of all the extractions were summed up ( $n=3$ replicates).

Sediment parameters of the soft bottom samples were estimated as follows: (I) water content as a relative weight loss (=percentage of fresh weight) after the drying of 10-g sediment material for $<24 \mathrm{~h}$ at $105^{\circ} \mathrm{C}$ in an oven. (II) The organic content of the dried samples (=percentage of dry weight) was quantified by combustion at $550{ }^{\circ} \mathrm{C}$ for a maximum of $4 \mathrm{~h}$. (III) Two hundred milligrams of dried sediment were taken for the determination of particulate organic carbon and nitrogen (POC:PON ratio) after homogenization of the particles using a mortar and a pistil. The resulting powder was wrapped in silver foil and treated with $50 \mu \mathrm{L}$ of $10 \%$ hydrochloric acid $(v / v)$, which removes inorganic carbonates. After this treatment, the sample was dried again and carefully packed in tin foil (air-tight to reduce atmospheric nitrogen). The combustion was conducted in an element analyzer (Vario EL III, Elementar; Langenselbold, Germany). (IV) The sediment particle size estimation was done with a particle size analyzer (Type 1180, Cilas Ltd., Orléans, France). Prior to these measurements, about 1 to $2 \mathrm{~g}$ of sediment sample was dispersed using deionized water, followed by homogenization through sonication for half an hour. In 12 replicate samples, the sediment particles were divided into 100 size classes between 0.37 and $<2000 \mu \mathrm{m}$. Size information from the particle analyzer was summarized to six different size categories 
(>1000, 1000-500, 500-200, 200-100, 100-63, and <63 $\mu \mathrm{m}$ ) and, afterwards, used for the calculation of the mean grain size of the soft bottom samples at both study sites, according to Reference [27].

Sediment pore water and surface water from the water column were analyzed for nutrient concentrations. Pore water of the upper $3 \mathrm{~cm}$ of the sliced sediment cores was obtained by centrifugation $(4860 \times g$, Heraeus Megafuge, Hanau, Germany) of the sediment sample inside of Teflon inlets with embedded sieves (mesh size $1 \mathrm{~mm}$ ). Before the subsequent analysis, pore water and surface water samples were passed through GF/F filters (Whatman, Maidstone, United Kingdom) to remove particles.

Nutrient concentrations of dissolved inorganic nitrogen (DIN-as sum of ammonium, nitrate, and nitrite concentrations) and soluble reactive phosphorus (SRP) were analyzed photometrically with UV 2401 (Shimadzu, Duisburg, Germany) according to the established protocols $[28,29]$. The content of silicate was quantified using the autoanalyzer Evolution III (Alliance Instruments, Salzburg, Austria) according to Reference [30].

\subsection{Primary Production and Respiration}

Optical $\mathrm{O}_{2}$ sensors (optodes) exhibit many methodological advantages compared to conventional oxygen measurement techniques, like the Winkler-method or Clark-electrode. $\mathrm{O}_{2}$ optodes typically show an enhanced sensitivity at low $\mathrm{O}_{2}$ concentrations and are not negatively influenced by $\mathrm{H}_{2} \mathrm{~S}$ [31], which is often present in sediments rich in organic compounds, and they do not consume oxygen. Small planar oxygen sensor spots with a diameter of $5 \mathrm{~mm}$ were positioned at the inner wall of air-tight Plexiglas ${ }^{\circledR}$ incubation chambers using a silicon glue. Any change in oxygen concentrations was recorded in the overlying aqueous phase above soft bottom cores using a commercial Fibox 3 system (PreSens $\mathrm{GmbH}$, Regensburg, Germany). The reproducibility of this type of $\mathrm{O}_{2}$ sensor is $\pm 0.5 \%$ at $85-\mu \mathrm{mol}$ oxygen $\mathrm{L}^{-1}$ and still $\pm 5 \%$ at $2.8 \mu \mathrm{mol} \mathrm{L}^{-1}$ (Presens, cited in Reference [32]). Two-point calibrations of the $\mathrm{O}_{2}$ sensors were performed in aerated $\left(100 \% \mathrm{O}_{2}\right.$ saturated) ambient sea water and in oxygen-free seawater treated with sodium dithionite solution. For details, see Reference [33].

All soft bottom cores were preincubated in the darkness at $5-7^{\circ} \mathrm{C}$, and signal recording was done at same temperatures as in the field using a temperature-controlled water bath (Titan 250, Aqua Medic, Bissendorf, Germany). A temperature logger "HOBO ${ }^{\circledR}$ Pendant" (Onset Computer corporation, Bourne, Massachusetts, USA) was positioned in a fourth blank sediment core and treated simultaneously to the three replicate cores. The incubation temperature in the core was logged every 10-20 s during each measuring period. For all measurements, sediment cores were at the beginning kept for $1 \mathrm{~h}$ in darkness to evaluate the oxygen consumption based on the community respiration followed by treatment with five increasing photon fluence rates to stimulate photosynthetic production each run for $30 \mathrm{~min}\left(\sum 2.5 \mathrm{~h}\right)$. The samples were increasingly irradiated with four halogen lamps (Olympus KL 1500 LCD, Hamburg, Germany) and four neon lamps (Osram Lumilux de Luxe Daylight, Munich, Germany) in steps of 20,50, 115, 150, and 200- $\mu$ mol photons $\mathrm{m}^{-2} \mathrm{~s}^{-1}$ (LICOR spherical quantum meter Li-192 SA, LiCor, Lincoln, NE, USA). Oxygen concentrations in the three replicate sediment cores were recorded every $15 \mathrm{~s}$. From the slope of $\mathrm{O}_{2}$ consumption in darkness (=respiration) and the $\mathrm{O}_{2}$ production in light (net primary production $=\mathrm{NPP}$ ), the $\mathrm{O}_{2}$ exchange rates were calculated. In a second step, the gross primary production rates (GPP) were calculated as the sum of respiration and NPP rates. Finally, these calculated GPP rates were normalized to an areal soft bottom surface $\left(\mathrm{mg} \mathrm{O}_{2} \mathrm{~m}^{-2} \mathrm{~h}^{-1}\right)$. The resulting $\mathrm{O}_{2}$ equivalents were transformed into carbon values $\left(\mathrm{mg} \mathrm{C} \mathrm{m}{ }^{-2} \mathrm{~h}^{-1}\right)$ to get rates comparable to other primary production studies using the widely applied photosynthetic quotient $\left(\mathrm{PQ}=\mathrm{DO}_{2} / \mathrm{DC}\right)$ of 1 [34].

\subsection{Diatom Visualization Using Scanning Electron Microscopy}

Selected sediment particles with epipsammic diatoms were visualized using a field emission scanning electron microscopy (SEM) that operated at $5 \mathrm{kV}$ (FE-SEM, MERLIN ${ }^{\circledR}$ VP 
Compact, Carl Zeiss, Oberkochen Germany, Faculty for Medicine, University of Rostock). Individual sand grains were picked using micro forceps under a binocular, followed by a gentle washing step in ultrapure water to get rid of salt from the sample and small particles. These cleaned sediment particles were fixed onto Aluminium SEM-carriers with adhesive conductive carbon tape (Co. PLANO, Wetzlar, Germany). The carriers were coated with carbon (5-10-nm layer) and, afterwards, inspected after exposure to a vacuum (EM SCD 500, Co. BALTEC, Balzers, Liechtenstein).

\subsection{Statistical Data Treatment}

The mean values of the estimated abiotic and biotic parameters were tested for statistically significant differences using one-way ANOVA, followed by a Tukey's multiple comparison test $(p<0.05)$ by which subgroups of significantly different means were denoted. In addition, and prior to these analyses, tests for equality of the variances [35] and normality [36] were undertaken. All statistical analyses were done with the software InStat (GraphPad Software Inc., La Jolla, CA, USA). The photosynthesis model of Reference [37] was applied to optimally fit respiration and photosynthesis rates under increasing light conditions using the Excel module Solver.

\section{Results}

\subsection{Abiotic Conditions and Sediment Properties}

Water temperatures at both stations at Boiensdorf ranged from $7.8^{\circ} \mathrm{C}$ in spring up to $26.1{ }^{\circ} \mathrm{C}$ in summer, while the salinity changes were less pronounced between 10.0 and 13.4 $\mathrm{S}_{\mathrm{A}}$, reflecting permanent brackish conditions (Table 1). The water depth over the months varied only between 2 and $49 \mathrm{~cm}$ (Table 1). The median soft bottom particle size was almost identical at both sampling sites, ranging from 131 to $138 \mu \mathrm{m}$, which is characteristic for fine sand. The average water content of the sediment was significantly different at both sampling site (site 1: $30.9 \pm 3.8$; site 2: $41.6 \pm 3.4 \%$ of fresh weight; $p<0.05$ ). In contrast, the average organic matter content and the average molar $\mathrm{C}: \mathrm{N}$ ratio of the sediments were similar between both sites, ranging from 15.1 to $21.7 \mathrm{mg} \mathrm{g}^{-1}$ dry weight and from 7.6 to $8.0(\mathrm{~mol} / \mathrm{mol})$, respectively (Table 1$)$. The organic matter content, however, showed high variability between the sampling months (Table 1). Nutrient concentrations expressed in $\mu \mathrm{mol} \mathrm{L}{ }^{-1}$ DIN (dissolved inorganic nitrogen), SRP (soluble reactive phosphorus), and silicate exhibited strong enrichment in the pore water versus surface water (Table 2). While DIN was three to 14-fold and SRP three to 23 times enriched over the course of the seasons, the silicate values revealed lower enrichment factors between two and five (Table 2).

Table 2. Range of nutrient concentrations in pore water (sediments) and surface water of both sampling stations no. 1 and 2 during the course of one year between October 2009 and October 2010 (three samplings: October, April, and July; $n=3$, respectively). Chemical parameters of the pore water are based on sediment slices to a $3-\mathrm{cm}$ sediment depth. DIN: dissolved inorganic nitrogen; SRP: soluble reactive phosphorus; all concentrations are given in $\mu \mathrm{mol} \mathrm{L}{ }^{-1}$.

\begin{tabular}{cccc}
\hline Station No. & DIN $\left(\mu \mathbf{m o l ~ L}^{-\mathbf{1}}\right)$ & SRP $\left(\mu \mathrm{mol} \mathrm{L}^{-\mathbf{1}}\right)$ & Silicate $\left(\mu \mathrm{mol} \mathrm{L}^{-\mathbf{1}}\right)$ \\
\hline 1 & $54-212$ & $5-31$ & $11-113$ \\
2 & $81-361$ & $7-51$ & $19-134$ \\
Surface water & $9-26$ & $0.5-2.2$ & $2-53$ \\
\hline
\end{tabular}

\subsection{Biomass of Benthic Diatoms}

The chl. $a$ concentration as proxy for the biomass of benthic diatoms was quantified in all soft bottom samples and normalized to a surface area of $1 \mathrm{~m}^{2}$. At station 1 (11-49 $\mathrm{cm}$ depth), the chlorophyll $a$ content ranged from $64.8 \mathrm{mg}$ Chl. $a \mathrm{~m}^{-2}$ in April 2012 to $138.5 \mathrm{mg}$ Chl. $a \mathrm{~m}^{-2}$ in July 2010 (Figure 2), with statistically significantly lower values in October 2011 and April 2012 (71.0 and $64.8 \mathrm{mg}$ Chl. $a \mathrm{~m}^{-2}, p<0.05$ ). At the shallower station 2 (2-12-cm depth), the chlorophyll $a$ concentrations were always higher and fluctuated less 
over the sampling dates compared to station 1 , with the values ranging mainly between 132.4 and $149.4 \mathrm{mg} \mathrm{Chl.} a \mathrm{~m}^{-2}$ (Figure 2). The only exception was the sampling date in October 2010, where $277.3 \mathrm{mg} \mathrm{Chl.} a \mathrm{~m}^{-2}$ could be determined (Figure 2).

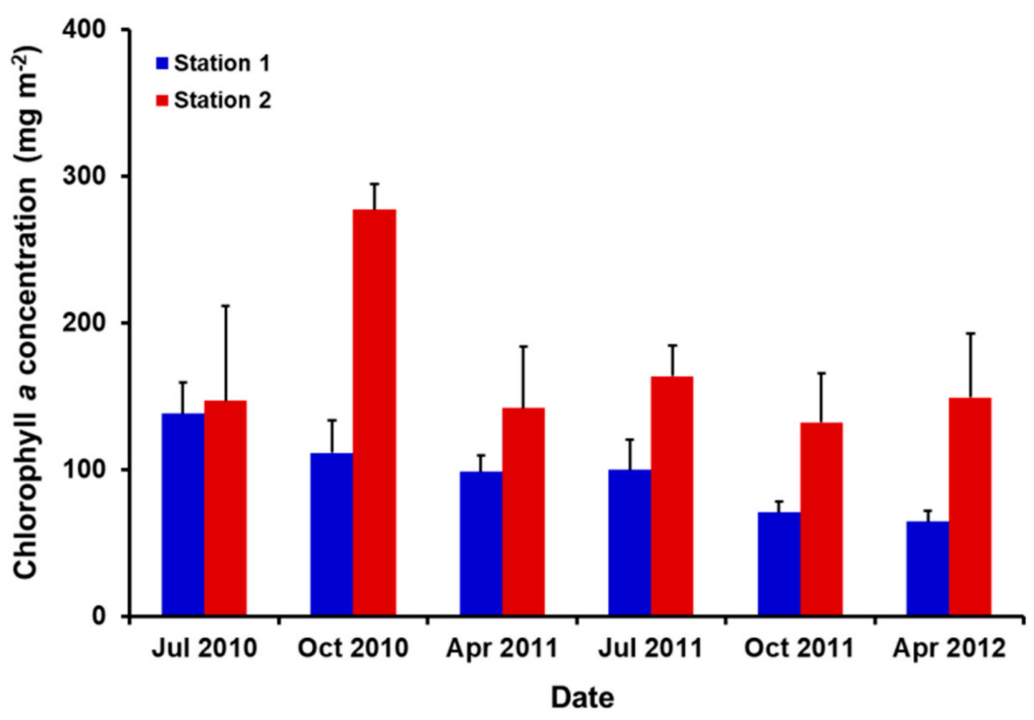

Figure 2. Chlorophyll $a$ concentration as a proxy for the biomass of benthic diatoms (chlorophyll $a \mathrm{mg} \mathrm{m}^{-2}$ ) in all soft bottom samples and normalized to a sediment surface area of $1 \mathrm{~m}^{2}$, as measured at two stations that differed in depth (S1: $11-49 \mathrm{~cm}$; S2: 2-12 cm). Sampling took place between July 2010 and April 2012. The data are given as mean values with standard deviation $(n=3)$. Different letters reflect significantly different mean values (Tukey's test, $p<0.05$ ).

\subsection{Benthic Diatom Primary Production and Respiration}

Photosynthetic and respiratory oxygen concentrations were measured with the oxygen optodes and referenced to a defined sediment surface area of $1 \mathrm{~m}^{2}$. Net primary production strongly varied between the sediment sampling dates and stations and ranged from 12.9 to $56.9 \mathrm{mg} \mathrm{O}_{2} \mathrm{~m}^{-2} \mathrm{~h}^{-1}$ (Figure 3). At station 1, the net primary production was similarly high in October 2010, October 2011, and April 2012 (49.4-54.0 $\mathrm{mg} \mathrm{O}_{2} \mathrm{~m}^{-2} \mathrm{~h}^{-1}$ ) and significantly lower in July 2010, April 2011, and July 2011 (12.9-30.8 $\mathrm{mg} \mathrm{O}_{2} \mathrm{~m}^{-2} \mathrm{~h}^{-1}, p<0.05$ ) (Figure 3). At station 2, the sediment cores from two sampling dates could not be measured due to technical problems. The remaining samples showed net primary production rates between 33.8 and $56.9 \mathrm{mg} \mathrm{O}_{2} \mathrm{~m}^{-2} \mathrm{~h}^{-1}$ (Figure 3).

The respiration rates also strongly fluctuated across the sampling dates and stations (Figure 4). Particularly in the summer (July 2010 and July 2011), the respiration rates were very high, as they exceeded the net primary production rates by a factor of 2.4-9.8 (Figure 4). Benthic diatom communities respired in a range from -6.4 to $-137.6 \mathrm{mg} \mathrm{O}_{2}$ $\mathrm{m}^{-2} \mathrm{~h}^{-1}$ (Figure 4).

From the net primary production and respiration rates, gross primary production could be calculated. The conversion of the $\mathrm{O}_{2}$ values into $C$, along with the utilization of a photosynthetic quotient $\left(\mathrm{PQ}=\Delta \mathrm{O}_{2} / \Delta \mathrm{C}\right)$ of 1 [34], resulted in a carbon-based measure $\left(\mathrm{mg} \mathrm{C} \mathrm{m}^{-2} \mathrm{~h}^{-1}\right)$. For the study site Boiensdorf across the sampling dates from July 2010 to April 2012, a gross primary production of $40.2-178.5 \mathrm{mg} \mathrm{C} \mathrm{m}^{-2} \mathrm{~h}^{-1}$ was finally calculated. 


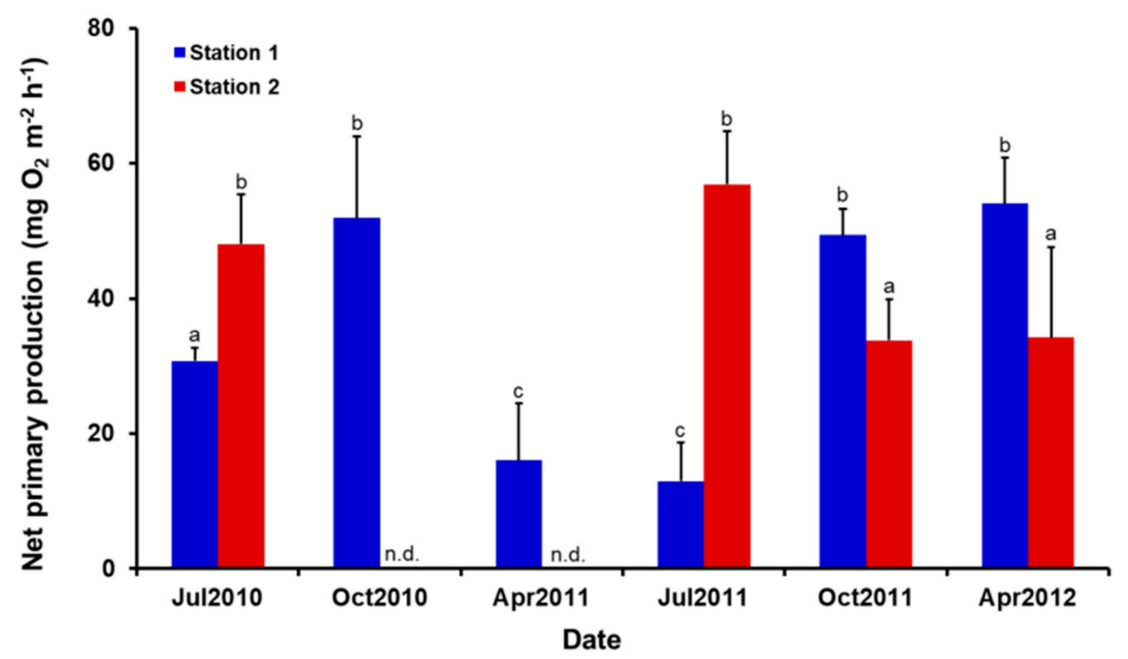

Figure 3. Ex situ net primary production rates (given as $\mathrm{mg} \mathrm{O}_{2} \mathrm{~m}^{-2} \mathrm{~h}^{-1}$ ) over the course of the seasons at both stations S1 and S2. The data are given as mean values with standard deviations $(n=3)$. Different letters reflect significantly different mean values (Tukey's test, $p<0.05$ ). n.d.: not detected.

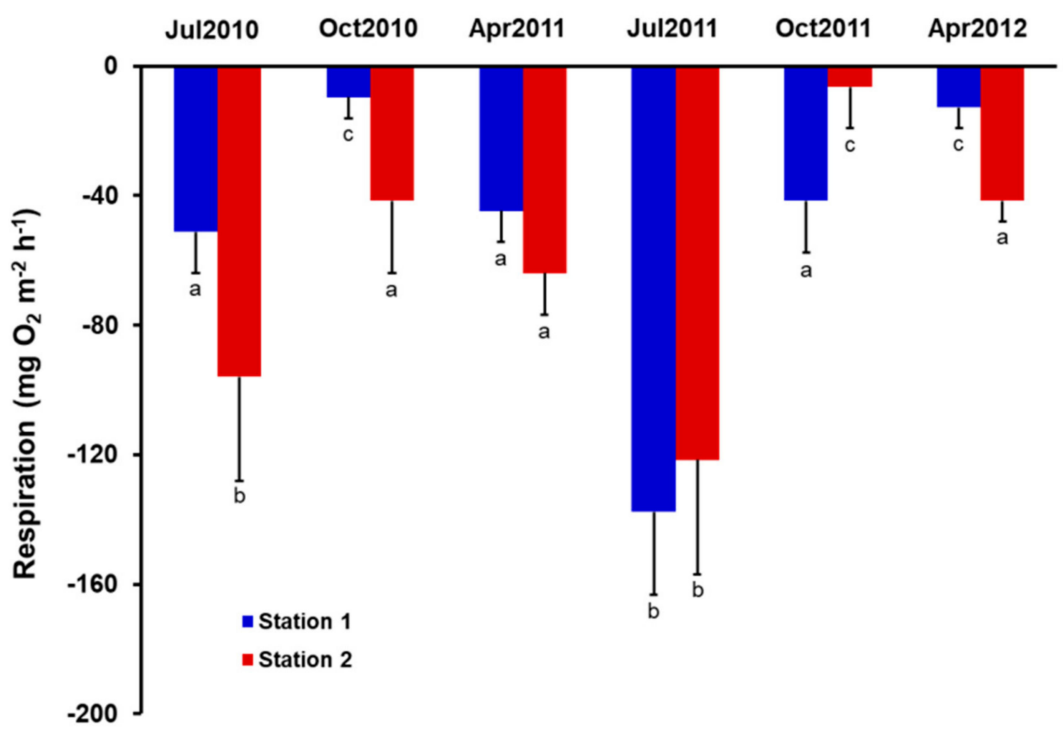

Figure 4. Ex situ respiratory oxygen consumption rates (given as $\mathrm{mg} \mathrm{O}_{2} \mathrm{~m}^{-2} \mathrm{~h}^{-1}$ ) over the course of the seasons at both stations S1 and S2. The data are given as the mean values with the standard deviation $(n=3)$. Different letters reflect significantly different mean values (Tukey's test, $p<0.05)$.

\subsection{Benthic Diatoms Attached to Sand Grains}

The fine sand particles from the Boiensdorf sites showed a homogeneous median grain size between 131 to $138 \mu \mathrm{m}$ and were angular-shaped with many edges (Figure 5b). These sand grains carried a high number of rather small epipsammic diatoms $(<10 \mu \mathrm{m})$, which formed dense communities (Figure 5c). 


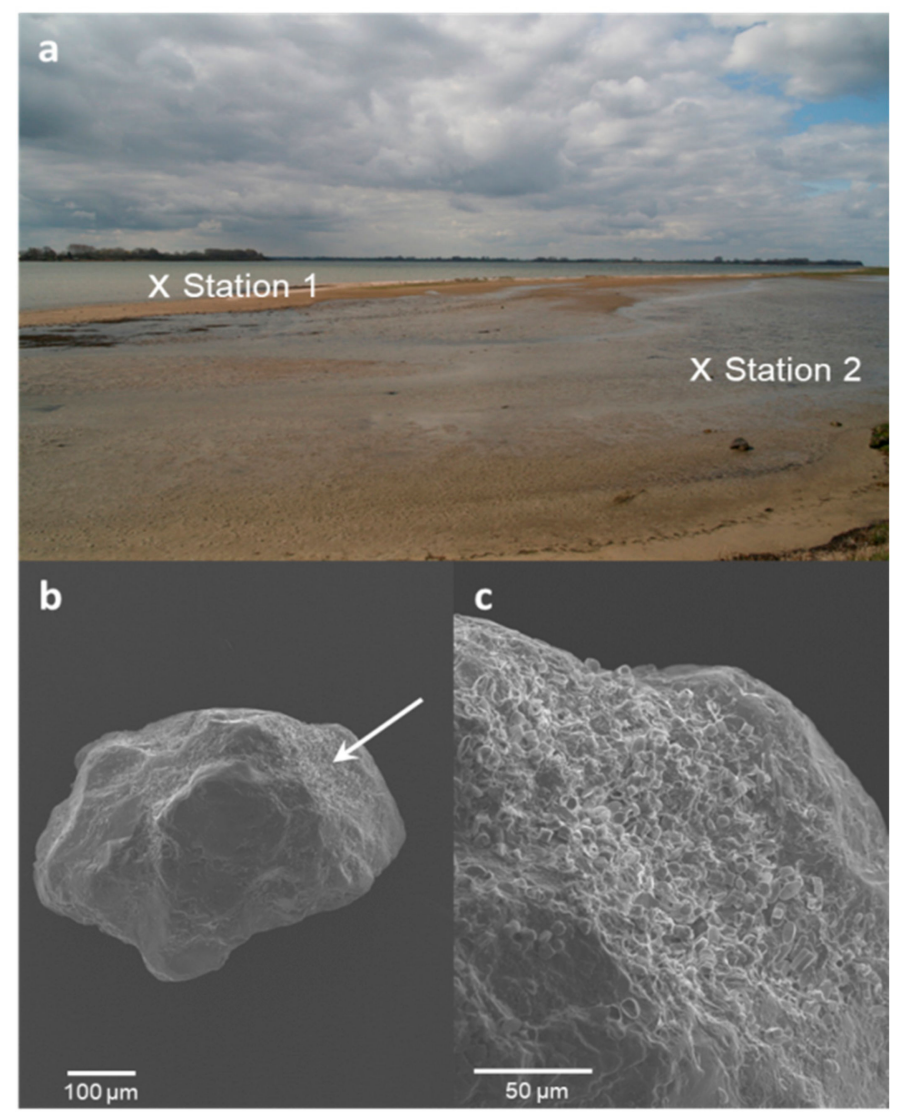

Figure 5. Typical picture of the sheltered sampling site at Boiensdorf on 17 April 2012 (a). Both sites S1 and S2 differ in the average water depth (see Table 1). Scanning electron microscopic images of sandy particles with epipsammic diatoms from this protected site $(\mathbf{b}, \mathbf{c})$. The sand grains are angular shaped with many edges carrying high numbers of small, attached diatoms $(<10 \mu \mathrm{m})$, which formed dense communities.

\section{Discussion}

At Boiensdorf, the protected sampling site is only $5-40 \mathrm{~cm}$ deep, and the influence of waves and currents can be neglected. Only strong winds from the northwest push water on the sediments resulting in higher water levels for short time periods. Similar effects of the prevailing wind fields have been reported for the so-called wind flat system Bock (Zingst Peninsula, German Baltic Sea coast, ca. $80 \mathrm{~km}$ east of Boiensdorf). Here, strong wind can at least temporarily lead to an irregular and unpredictable situation of emersion and flooding [5]. These authors documented over 30 months continuous measurements that the wind flat Bock was half of the time fully exposed and dry and the other half at least wet with a $<1-\mathrm{cm}$ water film or for short time periods flooded up to 20 and $50 \mathrm{~cm}$ of water height, particularly under stormy conditions (wind speed $>8 \mathrm{~m} \mathrm{~s}^{-1}$ ). Consequently, the sand grains at the sheltered Boiensdorf site were less mobile compared to exposed coastal sites [15] and, hence, typically exhibited a more angular shape (Figure 5a,b). In addition, under these relatively undisturbed conditions, chlorophyll $a$ and organic matter of the sediment were enriched (Table 1 and Figure 2). At Boiensdorf, the temperature amplitude was $7.8^{\circ} \mathrm{C}$ in the spring and up to $26.1^{\circ} \mathrm{C}$ in the summer (Table 1), while, in the open Baltic Sea, the maximum temperature in summer does not exceed $20^{\circ} \mathrm{C}$ [38]. The earlier measurements at Boiensdorf report seasonal changes in the water temperature from $-1{ }^{\circ} \mathrm{C}$ to $+28{ }^{\circ} \mathrm{C}$, reflecting a very strong amplitude over the course of the seasons [39]. The temperature along shallow beaches, as well as in lagoons and sheltered bays of the Southern Baltic Sea, is usually higher than in the nearby offshore area. At such sheltered sites, the water surface typically warms more quickly, as the mixing is less pronounced. 
In addition, at exposed coastal sites of the Southern Baltic Sea, such as in front of the Hütelmoor [1], the seasonal amplitude of temperature is rather small $\left(8.9-17.6{ }^{\circ} \mathrm{C}\right)$ because of irregular upwelling [40]. Therefore, it is reasonable to assume that microphytobenthic communities experience low hydrodynamic effects and rather favorable temperature conditions at Boiensdorf at most times of the year. This is in agreement with Reference [25], who confirmed a wide temperature tolerance for growth and photosynthesis in benthic diatoms isolated from Boiensdorf soft bottoms (all grew between $7^{\circ} \mathrm{C}$ and $27^{\circ} \mathrm{C}$, with optima between $18{ }^{\circ} \mathrm{C}$ and $24^{\circ} \mathrm{C}$ ). In addition, the sediment pore water is typically enriched in nutrients all over the seasons (Table 2), and hence, benthic diatoms do usually not suffer from nitrogen, phosphorus, or silicate limitation [6].

The study site was intensively characterized over two seasonal cycles in terms of changes in microphytobenthic community structure [39]. Benthic diatoms always dominated these communities with a relative abundance $>80 \%$, followed by a smaller proportion of mainly Chlorophyceae and Cyanobacteria. The benthic diatom community consisted of 42 taxa with cell numbers ranging from $2.73 \times 10^{5}$ to $1.36 \times 10^{6} \mathrm{~cm}^{-2}$ sediment surface over the course of the seasons [39]. More than $85 \%$ of the diatom taxa were small with $<20-\mu \mathrm{m}$ cell sizes. The most abundant species with a share of $77 \%$ was Opephora martyi (now Staurosirella martyi), followed by Achnanthes lanceolata (species complex, now Planothidium sp.), Amphora pediculus, Amphora veneta (now Halamphora veneta), Fragilaria subsalina (now Staurosira subsalina), Navicula phyllepta, and Navicula halophila (now Craticula halophila) [39].

Yellow substances, phytoplankton, and resuspended organic and inorganic particles shape the underwater light field in the offshore Baltic Sea, which attenuate the incident solar radiation by changing the optical properties of the water column. As a consequence, the light field is not only complex but also highly variable under different temporal scales. In contrast, at Boiensdorf, the water depth is only between 2 and $49 \mathrm{~cm}$, and hence, light attenuation can be neglected. The maximum photon flux density (PFD) can fluctuate between 389 and $2117 \mu \mathrm{mol}$ photons $\mathrm{m}^{-2} \mathrm{~s}^{-1}$, depending on diurnal and seasonal changes in insolation and cloud cover [25], which is generally sufficient to saturate the photosynthesis of benthic diatoms. This is confirmed by photosynthesis data on three benthic diatom isolates from Boiensdorf exhibiting light saturation points between 34 and $100-\mu \mathrm{mol}$ photons $\mathrm{m}^{-2} \mathrm{~s}^{-1}$ [25], as well as by the data of Reference [41], who also showed similar light saturation points (32-151- $\mathrm{mol}$ photons $\left.\mathrm{m}^{-2} \mathrm{~s}^{-1}\right)$ in eight benthic diatom species from the Southern Baltic Sea. Such members of microphytobenthic communities often show a high photophysiological plasticity, together with the ability to vertically move out of or into the upper sedimentary layer, thereby avoiding excessive solar radiation and, hence, photodamage [42]. Vertical movement, however, is restricted to rapid benthic diatom members. Consequently, behavioral and physiological photoprotection thus represent the key traits by which many benthic diatoms protect themselves against high incident sun light [43], and they are capable of adjusting their photosynthetic machinery relatively quickly to new radiation conditions [44]. Benthic diatoms, for example, can modify the size and/or composition of the photosynthetic units, which effect the electron transport capacity [45].

The applied planar oxygen optode approach used in the present study for measuring ex situ photosynthetic oxygen production and respiratory consumption of microphytobenthic communities was, for the first time, used by Reference [33] in the Arctic. These authors demonstrated the advantages of this technique, as the planar oxygen optodes allow the precise estimation of net production and respiration from undisturbed sediment cores with a known areal size without destructing the soft bottom particle layers. In addition, all environmental factors potentially affecting production and respiration can be easily controlled or simulated [15]. Although the ex situ approach integrates well the total sediment dwelling community activity, it provides only limited information on their vertical distribution and activity. Vertical oxygen measurements require microelectrode profiling to precisely characterize net production and respiration at any given depth point [44]. The disadvantage of such time-consuming vertical microelectrode profiling is the extrapolation 
of these numerous point measurements to larger soft bottom areas $\left(\mathrm{mm}^{2}\right.$ to $\mathrm{m}^{2}$ scale) because of high biomass patchiness. Our approach, however, integrates well the typical patchiness of benthic diatoms corresponding to a defined soft bottom surface of $19.6 \mathrm{~cm}^{2}$.

The concentrations of chl. $a$ at the sheltered site Boiensdorf varied between 64.8 and 277.3-mg Chl. $a \mathrm{~m}^{-2}$ across all sampling dates (Figure 2), and these amounts are higher compared to an exposed open coastal site about $40 \mathrm{~km}$ further east (28.0-87.7 mg Chl. $a \mathrm{~m}^{-2}$ ) [14]. Billerbeck et al. [46] reported chlorophyll a contents of 176-194-mg Chl. $a \mathrm{~m}^{-2}$ at two intertidal stations of the German Wadden Sea, while Reference [47] estimated 5-560-mg Chl. $a \mathrm{~m}^{-2}$ at an intertidal station of the Ems Dollard Estuary, The Netherlands. Similar values were found at other sampling sites of the southern Baltic Sea coast, where Reference [23] reported 135-209-mg Chl. $a \mathrm{~m}^{-2}$ for sheltered sediments in a coastal lagoon (Darss-Zingster Bodden). In contrast, Reference [24] measured lower values (20-122-mg Chl. $a \mathrm{~m}^{-2}$ ) over the course of all seasons from a rather exposed sandy beach in Poland. These data indicate that wind- and, hence, wave-protected sites of the Southern Baltic Sea coast, such as inner coastal waters and lagoons, seem to favor the development of benthic diatom communities. This is reflected in higher chlorophyll $a$ values compared to exposed and, hence, more mechanically disturbed coastal locations.

The community net primary production and respiration rates were derived from the oxygen flux measurements under increasing PFDs in the ex situ sediment core incubations. These $\mathrm{O}_{2}$ rates were mathematically transformed into $C$ equivalents applying the widely used photosynthetic quotient $\left(\mathrm{PQ}=\Delta \mathrm{O}_{2} / \Delta \mathrm{C}\right)$ of 1 [34]. The complete approach was successfully developed and tested under Arctic field conditions [33] and resulted in gross primary production rates of $13.4-59.5 \mathrm{mg} \mathrm{C} \mathrm{m}^{-2} \mathrm{~h}^{-1}$ at Boiensdorf between July 2010 and April 2012. Similar gross primary production rates $\left(16.3-74.0 \mathrm{mg} \mathrm{C} \mathrm{m}^{-2} \mathrm{~h}^{-1}\right)$ were calculated for an exposed offshore coastal site nearby for different shallow water depths and sampling dates [15]. All these rates are higher compared to 6-18 $\mathrm{mg} \mathrm{C} \mathrm{m}^{-2} \mathrm{~h}^{-1}$, which were reported for soft bottoms of a coastal lagoon (Southern Baltic Sea [23]), and to $0.2-41.8 \mathrm{mg} \mathrm{C} \mathrm{m}^{-2} \mathrm{~h}^{-1}$ recorded for different times of the year at a sandy beach (Southern Baltic Sea, Poland [24]). The analysis of $>40$ studies on the microphytobenthic gross primary production in temperate coastal waters $\left(30-60^{\circ} \mathrm{N}\right.$ and $\left.\mathrm{S}\right)$ indicated an average rate of $111 \mathrm{mg} \mathrm{C} \mathrm{m}^{-2} \mathrm{~h}^{-1}$ [6], which is more than the maximum rate of $59.5 \mathrm{mg} \mathrm{C} \mathrm{m}^{-2} \mathrm{~h}^{-1}$ in July 2011 at Boiensdorf but still reflects the important production and biological function of sheltered coastal regions of the Southern Baltic Sea. Nevertheless, microphytobenthic communities are still largely ignored in the Baltic Sea carbon budget, since phytoplankton is thought to be the key community for aquatic $C$ fixation [48]. However, there exists one recent investigation in which microphytobenthic communities of the Bothnian Bay (Northern Baltic Sea) contributed one-third of the total annual primary production [7], and [15] calculated for the Gulf of Gdańsk (Poland), based on published data, a share of $23 \%$ of the total primary production originating from benthic diatoms. These studies support well the view that coastal areas are among the most productive ecosystems on a global scale and that an array of benthic and pelagic phototrophic organisms is responsible for the total primary production [7].

Compared to earlier studies [33], the community respiration rates were partly high, particularly during the summer, when they strongly exceeded those of net primary production. At Boiensdorf, the heterotrophic activities enhanced as this site was sheltered and enriched in organic matter contents (Table 1), which probably stimulated microbial and other biological activities, thereby supporting a rich fauna [49].

\section{Conclusions}

Benthic diatoms are of production biological relevance at the shallow Southern Baltic Sea coast, but comprehensive data on primary production are still missing, particularly in space and time. Such data, however, are required for a fundamental understanding of a realistic carbon budget of the Baltic Sea, highlighting the input (production, biomass, etc.) and output (respiration, grazing, loss, etc.) fluxes. 
Author Contributions: Conceptualization, U.K. and T.H.; methodology, K.K. and J.W.; formal analysis, U.K. and J.W.; investigation, K.K. and J.W.; writing-original draft preparation, U.K. and J.W.; writing-review and editing, U.K., K.K., T.H., and J.W.; supervision, U.K. and T.H.; project administration, J.W.; and funding acquisition, U.K. and T.H. All authors have read and agreed to the published version of the manuscript.

Funding: This research was funded by the Federal Ministry of Education and Research of Germany (Bundesministerium für Bildung und Forschung; 03F0608O) in the framework of the Biological Impacts of Ocean Acidification (BIOACID) consortium (sub-project 1.1.5). This study was also conducted within the framework of the Research Training Group Baltic TRANSCOAST funded by the DFG (Deutsche Forschungsgemeinschaft) under grant number GRK 2000/1 (Subproject B2: Microphytobenthos). This is Baltic TRANSCOAST publication no. GRK2000/0049.

Institutional Review Board Statement: Not applicable.

Informed Consent Statement: Not applicable.

Data Availability Statement: Not applicable.

Acknowledgments: We thank P. Kumm (workshop of the Institute of Chemistry, University of Rostock) for assistance in the field and technical equipment. We are grateful to the Electron Microscopy Center of the University of Rostock, which supported the scanning electron microscopy.

Conflicts of Interest: The authors declare no conflict of interest.

\section{References}

1. Jurasinski, G.; Janssen, M.; Voss, M.; Böttcher, M.E.; Brede, M.; Burchard, H.; Forster, S.; Gosch, L.; Gräwe, U.; Gründling-Pfaff, S.; et al. Understanding the coastal ecocline: Assessing sea-land-interactions at non-tidal, low-lying coasts through interdisciplinary research. Front. Mar. Sci. 2019, 5, 342. [CrossRef]

2. Wolski, T.; Wiśniewski, B. Long-term, seasonal and short-term fluctuations in the water level of the southern Baltic Sea. Quaest. Geogr. 2014, 33, 181-197. [CrossRef]

3. Lass, H.U.; Magaard, L. Wasserstandsschwankungen und Seegang. In Meereskunde der Ostsee; Rheinheimer, G., Ed.; Springer: Berlin/Heidelberg, Germany, 1996; pp. 68-74.

4. Schwarzer, K. Dynamik der Küste 1996. In Meereskunde der Ostsee; Rheinheimer, G., Ed.; Springer: Berlin/Heidelberg, Germany, 1996; pp. 25-33.

5. Karsten, U.; Baudler, H.; Himmel, B.; Jaskulke, R.; Ewald, H.; Schumann, R. Short-term measurements of exposure and inundation of sediment areas in a tide-less wind flat system at the Southern Baltic Sea coast. J. Mar. Syst. 2012, 105-108, 187-193. [CrossRef]

6. Cahoon, L.B. The role of benthic microalgae in neritic ecosystems. Oceanogr. Mar. Biol. 1999, 37, 47-86.

7. Ask, J.; Rowe, O.; Brugel, S.; Strömgren, M.; Byström, P.; Andersson, A. Importance of coastal primary production in the northern Baltic Sea. Ambio 2016, 45, 635-648. [CrossRef]

8. Middleburg, J.J.; Barranguet, C.; Boschker, H.T.S.; Herman, P.M.J.; Moens, T.; Heip, C.H.R. The fate of intertidal microphytobenthos carbon: An in situ ${ }^{13}$ C-labeling study. Limnol. Oceanogr. 2000, 5, 1224-1234. [CrossRef]

9. Oakes, J.M.; Connolly, R.M.; Revill, A.T. Isotope enrichment in mangrove forests separates microphytobenthos and detritus as carbon sources for animals. Limnol. Oceanogr. 2010, 55, 393-402. [CrossRef]

10. Aslam, S.N.; Cresswell-Maynard, T.; Thomas, D.N.; Underwood, G.J.C. Production and characterization of the intra- and extracellular carbohydrates and polymeric substances (EPS) of three sea-ice diatom species, and evidence for a cryoprotective role for EPS. J. Phycol. 2012, 48, 1494-1509. [CrossRef]

11. De Brouwer, J.F.C.; Wolfstein, K.; Ruddy, G.K.; Jones, T.E.R.; Stal, L.J. Biogenic stabilization of intertidal sediments: The importance of extracellular polymeric substances produced by benthic diatoms. Microb. Ecol. 2005, 49, 501-512. [CrossRef]

12. Risgaard-Petersen, N.; Rysgaard, S.; Nielsen, L.P.; Revsbech, N.P. Diurnal variation of denitrification and nitrification in sediments colonized by benthic microphytes. Limnol. Oceanogr. 1994, 39, 573-579. [CrossRef]

13. Scholz, B.; Liebezeit, G. Growth responses of 25 benthic marine Wadden Sea diatoms isolated from the Solthörn tidal flat (southern North Sea) in relation to varying culture conditions. Diatom Res. 2012, 27, 65-73. [CrossRef]

14. Fredriksen, S.; Karsten, U.; Bartsch, I.; Woelfel, J.; Koblowsky, M.; Schumann, R.; Moy, S.; Steneck, B.; Hop, H.; Wiktor, J.; et al. Biodiversity of benthic micro- and macroalgae from Svalbard with special focus on Kongsfjorden. In The Ecosystem of Kongsfjorden, Svalbard; Advances in Polar Ecology; Hop, H., Wiencke, C., Eds.; Springer: Cham, Switzerland, 2019; Volume 2, pp. 331-371.

15. Kuriyama, K.; Gründling-Pfaff, S.; Diehl, N.; Woelfel, J.; Karsten, U. Microphytobenthic primary production on exposed coastal sandy sediments of the Southern Baltic Sea using ex-situ sediment cores and oxygen optodes. Oceanologia 2021, 63, 247-260. [CrossRef]

16. Woelfel, J.; Schumann, R.; Adler, S.; Hübener, T.; Karsten, U. Diatoms inhabiting a wind flat of the Baltic Sea: Species diversity and seasonal succession. Estuar. Coast. Shelf Sci. 2007, 75, 296-307. [CrossRef] 
17. Sabbe, K. Short-term fluctuations in benthic diatom numbers on an intertidal sandflat in the Westerschelde estuary (Zeeland, The Netherlands). Hydrobiologia 1993, 269/270, 275-284. [CrossRef]

18. Orvain, F.; Lefebvre, S.; Montepini, J.; Sébire, M.; Gangnery, A.; Sylvand, B. Spatial and temporal interaction between sediment and microphytobenthos in a temperate estuarine macro-intertidal bay. Mar. Ecol. Prog. Ser. 2012, 58, 53-68. [CrossRef]

19. Daggers, T.D.; Kromkamp, J.C.; Herman, P.M.J.; van der Wal, D. A model to assess microphytobenthic primary production in tidal systems using satellite remote sensing. Remote Sens. Environ. 2018, 211, 129-145. [CrossRef]

20. Frankenbach, S.; Ezequiel, J.; Plecha, S.; Goessling, J.W.; Vaz, L.; Kühl, M.; Dias, J.M.; Vaz, N.; Serôdio, J. Synoptic spatio-temporal variability of the photosynthetic productivity of microphytobenthos and phytoplankton in a tidal estuary. Front. Mar. Sci. 2020, 7, 170. [CrossRef]

21. Wasmund, N. Ecology and bioproduction in the microphytobenthos of the chain of shallow inlets (Boddens) south of the Darss-Zingst Peninsula (Southern Baltic Sea). Int. Rev. Ges. Hydrobiol. 1986, 71, 153-178. [CrossRef]

22. Yap, H.T. Benthic energy dynamics in a southern Baltic ecosystem. Mar. Biol. 1991, 108, 477-484. [CrossRef]

23. Meyercordt, J.; Meyer-Reil, L.A. Primary production of benthic microalgae in two shallow coastal lagoons of different trophic status in the southern Baltic Sea. Mar. Ecol. Prog. Ser. 1999, 178, 179-191. [CrossRef]

24. Urban-Malinga, B.; Wiktor, J. Microphytobenthic primary production along a non-tidal sandy beach gradient: An annual study from the Baltic Sea. Oceanologia 2003, 45, 705-720.

25. Woelfel, J.; Schoknecht, A.; Schaub, I.; Enke, N.; Schuhmann, R.; Karsten, U. Growth and photosynthesis characteristics of three benthic diatoms from the brackish southern Baltic Sea in relation to varying environmental conditions. Phycologia 2014, 53, 639-651. [CrossRef]

26. Jeffrey, S.W.; Humphrey, G.F. New spectrophotometric equations for determining chlorophylls $A, B, C_{1}$ and $C_{2}$ in higher plants, algae and natural phytoplankton. Biochem. Physiol. Pflanz. 1975, 167, 191-194. [CrossRef]

27. Wentworth, C.K. A scale of grade and class terms for clastic sediments. J. Geol. 1922, 30, 377-392. [CrossRef]

28. Rohde, K.H.; Nehring, D. Ausgewählte Methoden zur Bestimmung von Inhaltsstoffen im Meer- und Brackwasser. In Reihe IV/27, Physik der Flüssigen Erde; Nationalkomitee für Geodäsie und Geophysik der Akademie der Wissenschaften der DDR: Berlin, Germany, 1979; pp. 31-37.

29. Malcom-Lawes, D.J.; Wong, K.H. Determination of orthophosphate in water and soil using a flow analyzer. Analyst 1990, 115, 65-67. [CrossRef]

30. Hansen, H.P.; Koroleff, F. Determination of nutrients. In Methods of Seawater Analysis; Grasshoff, K., Ehrhardt, M., Kremling, K., Eds.; Verlag Chemie: Weinheim, Germany, 1983; pp. 159-226.

31. Kühl, M.; Polerecky, L. Functional and structural imaging of phototrophic microbial communities and symbioses. Aquat. Microb, Ecol. 2008, 53, 99-118. [CrossRef]

32. Warkentin, M.; Freese, H.; Karsten, U.; Schumann, R. New and fast method to quantify respiration rates of bacterial and plankton communities in freshwater ecosystems by using optical oxygen sensor spots. Appl. Environ. Microbiol. 2007, 73, 6722-6729. [CrossRef] [PubMed]

33. Woelfel, J.; Schumann, R.; Peine, F.; Flohr, A.; Kruss, A.; Tegowski, J.; Blondel, P. Microphytobenthos of Arctic Kongsfjorden (Svalbard, Norway): Biomass and potential primary production along the shore line. Polar Biol. 2010, 33, 1239-1253. [CrossRef]

34. Hargrave, B.T.; Prouse, N.J.; Phillips, G.A.; Neame, P.A. Primary production and respiration in the pelagic and benthic communities at two intertidal sites in the upper Bay of Fundy. Can. J. Fish. Aquat. Sci. 1983, 40, 229-243. [CrossRef]

35. Levene, H.; Olkin, I.; Hotelling, H. Robust tests for equality of variances. In Contributions to Probability and Statistics. Essays in Honor of Harold Hotelling; Stanford University Press: Palo Alto, CA, USA, 1960; pp. 78-92.

36. Shapiro, S.S.; Wilk, M.B. An analysis of variance test for normality (complete samples). Biometrika 1965, 52, 591-611. [CrossRef]

37. Webb, W.L.; Newton, M.; Starr, D. Carbon dioxide exchange of Alnus rubra-A mathematical model. Oecologia 1974, 17, 281-291. [CrossRef]

38. HELCOM. Available online: https://helcom.fi/wp-content/uploads/2020/07/BSEFS-Sea-Surface-Temperature-in-the-BalticSea-2018.pdf (accessed on 31 August 2021).

39. Bernt, A. Trophische Beziehungen Zwischen Benthischen Diatomeen (Bacillariophyceae) und Amphichaeta sannio (Oligochaeta, Naididae). PhD Dissertation, Universität Rostock, Rostock, Germany, 2001; p. 111.

40. Lehmann, A.; Myrberg, K. Upwelling in the Baltic Sea-A review. J. Mar. Syst. 2008, 74, 3-12. [CrossRef]

41. Prelle, L.R.; Graiff, A.; Gründling-Pfaff, S.; Sommer, V.; Kuriyama, K.; Karsten, U. Photosynthesis and respiration of Baltic Sea benthic diatoms to changing environmental conditions and growth responses of selected species as affected by an adjacent peatland (Hütelmoor). Front. Microbiol. 2019, 10, 1500. [CrossRef]

42. Ezequiel, J.; Laviale, M.; Frankenbach, S.; Cartaxana, P.; Serôdio, J. Photoacclimation state determines the photobehaviour of motile microalgae: The case of a benthic diatom. J. Exp. Mar. Biol. Ecol. 2015, 468, 11-20. [CrossRef]

43. Cartaxana, P.; Ruivo, M.; Hubas, C.; Davidson, I.; Serôdio, J.; Jesus, B. Physiological versus behavioral photoprotection in intertidal epipelic and epipsammic benthic diatom communities. J. Exp. Mar. Biol. Ecol. 2011, 405, 120-127. [CrossRef]

44. Glud, R.N.; Kühl, M.; Wenzhöfer, F.; Rysgaard, S. Benthic diatoms of a high Arctic fjord (Young Sound, NE Greenland): Importance for ecosystem primary production. Mar. Ecol. Prog. Ser. 2002, 238, 15-29. [CrossRef]

45. Richardson, K.; Beardall, J.; Raven, J.A. Adaptation of unicellular algae to irradiance: An analysis of strategies. New Phytol. 1983, 93, 157-191. [CrossRef] 
46. Billerbeck, M.; Roy, H.; Bosselmann, K.; Huettel, M. Benthic photosynthesis in submerged Wadden Sea intertidal flats. Estuar. Coast. Shelf Sci. 2007, 71, 704-716. [CrossRef]

47. Colijn, F.; De Jonge, V.N. Primary production of microphytobenthos in the Ems-Dollard Estuary. Mar. Ecol. Prog. Ser. 1984, 14, 185-196. [CrossRef]

48. Schiewer, U. Ecology of Baltic Coastal Waters; Ecological Studies 197; Springer: Berlin/Heidelberg, Germany, 2008.

49. Borck, D.; Frenzel, P. Micro-habitats of brackish water ostracods from Poel Island, southern Baltic Sea coast. Senck. Marit. 2006, 36, 99-107. [CrossRef] 